\title{
A Coxian Approach: Mengungkap Hegemoni Agenda "Education For All” terhadap Negara Berkembang
}

\author{
Indra Kusumawardhana \& Arry Bainus \\ Universitas Pertamina \& Universitas Padjadjaran
}

\begin{abstract}
ABSTRAK
Artikel ini berfokus kepada dinamika agenda Education for All (EFA) sebagai agenda pendidikan dunia yang telah digaungkan sejak dua dasawarsa kebelakang. Ironisnya, setelah 15 tahun EFA dilaksanakan hingga paripurna di tahun 2015 silam, realitas implementasi dari EFA sebagai komitmen dunia tidak seindah tujuan mulia yang disuarakan. Berdasarkan problematika tersebut, pertanyaan utama yang akan diajukan dalam artikel ini adalah bagaimana EFA sebagai agenda pendidikan global membenamkan hegemoni terhadap trajektori kebijakan pendidikan negara-negara berkembang? Melalui pendekatan Cox dalam memahami World Orders sebagai sebuah arena tempat kekuatan sosial diproduksi; artikel ini mengklaim bahwa hegemoni etis EFA sebagai sebuah agenda pendidikan dunia terhadap negaranegara berkembang berpijak pada proses institutionalisasi agenda pendidikan secara global menggunakan keberadaan organisasi internasional, kapasitas material agenda yang ditopang oleh negara-negara maju, dan ide universal untuk membangun konsensus global terkait trajektori pendidikan dunia.
\end{abstract}

Kata-kata kunci: Education For All, Hegemoni Etis, Agenda Pendidikan Global, Negara Berkembang

This article probes on the dynamics of the Education for All (EFA) as global eduaction agenda that has been echoed in the past two decades. Ironically, after 15 years of EFA implementation until the plenary in 2015, the result of EFA as world commitment is not as beautiful as the noble goal it echoes. In the light of this view, the main question that will be asked in this article is how EFA as the global education agenda immerses its ethical hegemony over the education policy trajectory of developing countries? using Coxian approach in understanding World Orders as an arena where social forces are produced, this article argues that the foundation of EFA's ethical hegemony as a global education agenda for developing countries today are revealed in the institutionalization process of the global educational agenda the world's commitment aggregated using the existence of international organizations, the material capacity of the agenda is sustained by the developed countries through the availability of funds promoting the agenda; and the universal idea to build a global consensus related to the world education trajectory.

Keywords: Education For All, Ethical Hegemony, Global Education Agenda, Developing Countries 
Agenda pendidikan dunia yang dibicarakan di dalam artikel ini fokus kepada dinamika agenda Education for All (EFA) yang telah digaungkan sejak dua dasawarsa lalu. Menurut Colin Power (2014),

"The Education for All (EFA) movement is a global movement committed to providing quality basic education for all children, youth and adults. The movement stemmed from concerns voiced by UNESCO, UNICEF and developing countries about the growing number of children, youth and adults whose right to even the most basic education was being denied".

Gerakan ini berawal dari Konferensi Dunia di Jomtien, Thailand pada tahun 1990 ketika muncul suatu gagasan besar yang mendorong komitmen global terhadap trajektori pendidikan dunia yang menggema dengan jargon "Education for All" (EFA) (UNESCO 2016). Pada tahun 2000, adicita tersebut ditindaklanjuti oleh komunitas internasional, melalui terselenggaranya konvensi bertajuk World Education Forum di Dakkar yang menghasilkan kerangka aksi bersama (Dakkar Framework for Action), disetujui oleh 164 pemerintahan negara untuk dapat bekerja keras mewujudkan tujuan global terkait dengan pendidikan (UNESCO 2000).

Ironisnya, setelah 15 tahun EFA menjadi agenda kebijakan pendidikan global, realitas implementasi dari EFA sebagai komitmen dunia tidak seindah tujuan mulia yang disuarakan. Hasrat untuk menjadi agenda bersama dalam konteks universal primary education yang dapat diterapkan secara ekstensif menegaskan kenyataan bahwa setiap negara memiliki kondisi ekonomi, politik dan sosial yang berbeda. Artikel ini memandang bahwa, dua dasawarsa pelaksanaan EFA, menjadi momentum yang tepat untuk mengungkap sisi-sisi lain dari tujuan mulia EFA sebagai agenda pendidikan Global. Pertanyaan utama yang akan diajukan dalam artikel ini adalah bagaimana EFA sebagai agenda pendidikan global membenamkan hegemoni etisnya terhadap trajektori kebijakan pendidikan negara-negara berkembang? Argumen utama artikel ini berpijak pada pendekatan Cox dalam memahami World Orders sebagai sebuah arena tempat kekuatan sosial diproduksi melalui artikulasi kapasitas material, ide-ide dan institusi yang bergerak secara dinamis di era globalisasi dewasa ini, keberadaan tiga aspek lintas batas tersebut yang menjadi pondasi blok historis dari hegemoni EFA sebagai sebuah agenda pendidikan dunia terhadap negara-negara berkembang saat ini.

\section{Globalisasi Pendidikan dan Hegemoni: A Coxian Approach}

Menurut beberapa pakar, globalisasi adalah deteritorialisasi sosial, politik, dan hubungan ekonomi, serta integrasi cepat antara masyarakat yang sebelumnya terikat batas wilayah yaitu disebut negara-bangsa (Harvey 1989; Ruggie 1993). Sedangkan Globalisasi pendidikan, dalam tulisan ini, dipahami sebagai globalisasi pendidikan merujuk pada jaringan, proses, dan lembaga di seluruh dunia yang mempengaruhi praktik dan kebijakan pendidikan lokal (Spring 2014). Secara luas, globalisasi pendidikan menurut Spring nampak dari realitas bahwa terdapat jaringan organisasi internasional yang berpengaruh secara langsung dan tidak langsung terhadap sistem sekolah nasional bersama dengan perusahaan dan sekolah Pendidikan multinasional. Adapun institusi global yang memiliki pengaruh kuat dalam membentuk kebijakan 
terkait dengan pendidikan dunia adalah Organization for Economic Cooperation (OECD); World Bank; United Nations Educational, Scientific, and Cultural Organization (UNESCO); World Trade Organization (WTO) dan berbagai organisasi internasional yang terkantong-kantong dalam berbagai isu global dewasa ini (Spring 2015). Secara kritis tulisan ini melihat; setiap kehadiran sebuah institusi yang memiliki karakter supranasional seperti World Bank, OECD dan UNESCO yang ternyata juga memiliki kepedulian terhadap arah agenda pendidikan dunia ini, seketika itu juga tulisan ini sepakat dengan pandangan Robert W. Cox bahwa "Theory is always for someone, and for some purpose" $(1981,128)$. Pada titik ini, konsep hegemoni menemukan arti pentingnya untuk membuka cakrawala tulisan ini dalam memahami EFA sebagai sebuah agenda pendidikan dunia.

Konsep hegemoni di dalam Hubungan Internasional dihadirkan oleh Robert Cox selaku perintis pendekatan kritis dengan meminjam buah pemikiran progresif Gramsci, seorang Marxis Italia. Karya-karya progresif Gramsci yang terdapat di dalam berbagai catatan penjara ketika menjadi tahanan politik di bawah rezim Mussolini telah memberikan ilham terhadap cendekia ilmu sosial setelah zamannya, termasuk Cox yang menggunakannya sebagai batu loncatan dalam memahami hegemoni di dalam sistem internasional. Oleh karenanya, memahami pemikiran Gramsci sangat penting sebagai pintu masuk pendekatan tulisan ini. Hegemoni di dalam pemikiran Gramsci digambarkan sebagai berikut, hegemoni bertumpu pada kemampuan kelas dominan untuk membentuk hubungan konsensual dengan kelas-kelas subaltern melalui berbagai saluran sosial dan budaya (Gramsci 1971, 55-60; 415-25). Dalam perspektif ini, kekuasaan dikonstruksikan bukan melalui koersi, kekerasan, ataupun paksaan, melainkan dengan menggunakan konsensus dan kontrol (Cox dalam Sugiono 1999, 35).

Kerja intelektual Cox (1981) beranjak lebih jauh dalam mengelaborasikan konsep Gramsci tentang basis struktur dan superstruktur, dalam upaya kritisnya meretas pendekatan alternatif di dalam teori hubungan internasional. Cox memainkan fleksibilitas pemahaman Gramsci tentang relasi kekuasaan di dalam masyarakat domestik dengan mengangkat peringkat analisisnya untuk menelaah relasi kekuasaan di dalam sistem internasional. Robert Cox menggambarkan hegemoni sebagai suatu manifestasi struktur sosial, ekonomi, dan politik yang diekspresikan dalam bentuk norma-norma universal, institusi-institusi, dan mekanisme-mekanisme yang mendasari aturan dan tingkah laku negara serta civil society yang melampaui batas-batas nasional-suatu tatanan yang menopang mode produksi yang dominan (Hadiwinata 2002, 47). Dalam konteks menciptakan tatanan, menurut Cox ada tiga macam kekuatan yang berinteraksi di dalam struktur yang disinggung oleh Gramsci yaitu kapasitas material, ide, dan institusi-institusi. Hegemoni kemudian menuntut ketiganya berinteraksi secara resiprokal dalam mengartikulasikan potensi-potensi untuk melakukan rekonfigurasi kekuatan sosial. Kesesuaian antara kekuatan material, ideologi, dan institusi, hegemoni mungkin tampak meminjamkan dirinya pada teori siklus sejarah; ketiga dimensi tersebut saling melengkapi dalam waktu dan tempat tertentu dan terpisah dari yang lain. Penekanan terhadap sifat interaksinya yang berpola serupa siklus di dalam sejarah menjadikan aspek-aspek tersebut tidak memiliki sistematika yang kaku namun lebih bersifat lentur dan interaktif saling mempengaruhi secara resiprokal. 


\section{Gambar.1}

\section{Three Categories of Forces}

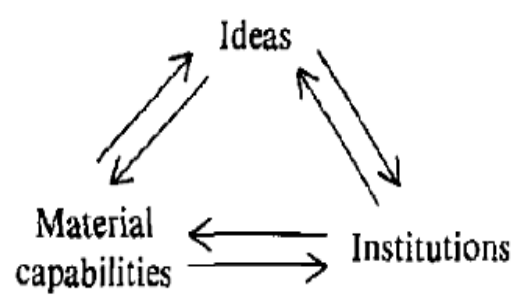

Figure 1

Sumber: Cox, R.W., 1981. "Social forces, states and world orders: beyond international relations theory" Millennium, 10(2), pp.126-155.

Aspek pertama adalah Institusionalisasi, dengan potensi institusionalisasi dalam pemahaman politik sebagai alat untuk melakukan stabilisasi, penyelarasan dan pelanggengan sebuah tatanan sosial. Menurut Cox (1981), institusi merefleksikan relasi kekuatan yang berlaku di titik asal dan cenderung, setidaknya pada awalnya, untuk mendorong citra kolektif yang konsisten dengan relasi kekuatan ini. Di dalam pemahaman kritis tulisan ini, institusi selalu memiliki kecenderungan politis karena ketidakberdayaannya terhadap relasi kekuasaan antar aktoryang menjadi entitas politik di dalamnya. Karena institusi menyediakan kanal-kanal untuk mengatur konflikkonflik internal, bahkan mencegah penggunaan kekuatan dalam bentuk apapun. Adapun pemahaman tersebut dijelaskan oleh Cox sebagai berikut, institusi dapat menjadi jangkar untuk strategi hegemonik seperti itu karena mereka meminjamkan diri mereka baik kepada representasi dari berbagai kepentingan dan untuk universalisasi kebijakan (Cox 1981, 137). Trajektori tata kelola pendidikan global yang semakin menunjukan proses pelembagaan ataupun institutionalisasi menemukan relevansinya dengan pandangan ini sehingga keberadaanya tidak bisa dipisahkan dengan potensi munculnya hegemoni etis di berbagai agenda yang dipromosikannya.

Kemudian, kapasitas material (Material Capabilities) menjadi dimensi kekuatan kedua yang menurut Cox memainkan peran potensi-potensi destruktif dan produktif. Seperti yang dijelaskan oleh Cox sebagai berikut,

\section{"Intheirdynamicformtheseexistastechnologicalandorganisational capabilities, and in their accumulated forms as natural resources which technology can transform, stock equipment (e.g industries and armaments), and the wealth which can command these".}

Menurut pemahaman tulisan ini, di dalam wujudnya yang dinamis, ada tiga aspek penting dalam memahami artikulasi dari kapasitas material dari kekuatan-kekuatan sosial di dalam struktur hegemon yakni kapasitas organisatoris, penggalangan dana secara ekstensif, dan penguasaan teknologi di ranah praktis dapat menjadi instrumen untuk mengkonsolidasikan konsensus antar aktor negara maupun non-negara di dalam sistem internasional. Dimensi kekuatan ide menjadi yang ketiga, kekuatan ide berdasarkan penjelasan Cox, memuat dua bentuk; intersubjektif dan kolektif. 
Pertama, ide yang memainkan peran sebagai kekuatan intersubjektif di dalam benak antar aktor, adapun makna-makna intersubjektif yang direproduksi aktor di dalam interaksinya berperan sebagai makna bersama yang melandasi hakikat alami hubungan antar aktor di dalam sistem internasional. Keberadaan makna bersama sangat penting karena mampu memunculkan semacam ekspektasi dan pola hubungan yang dianggap wajar dari perilaku aktor di dalam sistem sosial. Sedangkan bentuk kedua dari ide, memainkan peran untuk memunculkan citra bersama (Collective Images) yang dipatuhi sebagai sebuah tatanan di dalam sistem sosial. Keberadaan citra bersama memberikan pemahaman terhadap aktor terkait sifat alami dan legitimasi dari relasi kekuasaan yang unggul, makna keadilan dan kebaikan publik, dan seterusnya (Cox 1981, 136). Menggunakan ketiga konsep utama tersebut, kerangka pemikiran yang dibangun oleh tulisan ini akan membedah secara mendalam EFA sebagai agenda pendidikan global, mengungkap hegemoninya terhadap negara-negara berkembang yang tidak kuasa menghadapi relasi kekuasaan yang ada di dalam agenda-agenda tersebut.

\section{Institusi dan Kapasitas Material Di Dalam Agenda EFA}

Seperti telah disinggung sebelumnya, terdapat tiga ragam kekuatan yang berinteraksi di dalam struktur yang mengekspresikan hegemoni yakni institusi - institusi, kapasitas Material, serta ide - ide (terbagi menjadi dua macam; intersubjektif dan citra kolektif). Kekuatan pertama adalah Institusi; bertolak dari pemahaman Cox, Institutionalisasi (Institutionalisation) merupakan alat untuk menstabilisasi serta melanggengkan tatanan tertentu di dalam sistem sosial. Adapun manifestasi keberadaannya di dalam institusi-institusi yang berkembang berdasarkan pada amalgamasi dari ide-ide dan kekuatan material yang kemudian mempengaruhi perkembangan serta kristalisasi ide-ide dan kapasitas material di dalam struktur. Meminjam pemahaman John Gerard Ruggie (1998), secara sosiologis, Ruggie mengejawantahkan institutionalisasi sebagai upaya untuk mengoordinasikan dan perilaku pola, untuk menyalurkannya dalam satu arah daripada ke banyak arah yang secara teoritis dan empiris mungkin. Dalam konteks EFA, untuk mendorong negara menuju kesatuan trajektori bersama, dibutuhkan aktor non-state yang bisa melakukan reproduksi agenda dan wacana universal yang dianggap mampu mengakomodasi ekspektasi bersama negara-negara dunia. Menurut Cox sendiri, organisasi internasional menjadi institusi penting di dalam tatanan dunia, terutama sebagai arena sosial yang digunakan untuk menegakkan hegemoni norma universal. Keberadaan organisasi internasional memainkan fungsinya sebagai wadah tempat institusi-institusi hegemon beserta ideologinya dikembangkan serta dikonstruksikan secara ekstensif di lapangan global (Cox 1983, 172).

Berdasar pada pemahaman tersebut, institutionalisasi di dalam agenda pendidikan global dapat kita retas melalui penelusuran keberadaan UNESCO sebagai organisasi internasional yang memimpin gerak laju agenda EFA. UNESCO yang pada awal berdirinya merupakan manifestasi pemikiran negara-negara di Eropa yang sedang menghadapi krisis sistem pendidikan akibat perang serta desakan British Workers Educational Association, International peace Network dan International Federations of Teacher terhadap pendiri Liga Bangsa-Bangsa untuk menyertakan isu pendidikan dalam organ institusinya yang pada akhirnya menjadi sebuah institusi global di bawah United Nations yang memiliki kerangka kerja menentukan diskursus pendidikan dunia (Fuchs 2007, 398). Kendati bersama OECD dan World Bank; UNESCO berbagi 
jaringan pendidikan global yang menentukan alternatif ideal sistem pendidikan dunia (Spring 2014). Dalam fungsi ini, UNESCO berkontribusi terhadap tata-kelola diskursus global terkait pendidikan terutama seputar pendidikan sepanjang hayat (Lifelong Learning Education) yang terbalut oleh nuansa adicita yang lebih humanis dibandingkan World Bank dan OECD yang condong pada kepentingan ekonomi dalam melihat pendidikan (Singh 2002, 18).

Namun UNESCO dalam perdebatan narasi tujuan ideal pendidikan pada tingkat global ini didukung oleh International Commission on the Development of Education, bahkan diminta oleh United Nations General Assembly untuk memimpin program pendidikan dunia menuju sustainable development sejak 2002 hingga 2014. Dalam kaitan ini UNESCO terlibat langsung untuk mengkonsolidasikan kekuatan global untuk mengimplementasikan skema United Nations terkait dengan pendidikan untuk satu dekade kedepan (UNESCO Implementation Scheme). Ipso Facto, wacana tujuan pendidikan di tingkat global dimenangkan oleh UNESCO (Lifelong Learning) dan pada titik inilah diskursus mengenai "Education for All" mendapatkan tempat untuk bermain dalam dinamika hubungan internasional dunia. Meskipun diskursus EFA telah disuarakan sejak tahun 1990-an, namun minimnya tingkat kemapanan ekonomi negara-negara berkembang dan terbelakang pada masa itu menjadi halangan utama untuk agenda EFA diterapkan secara ekstensif kala itu (Benavot et al. 2016).

Akhirnya agenda EFA menemukan momentum utamanya pada tahun 200o, lebih dari 1.000 anggota komunitas internasional berkumpul di Dakkar, Senegal, pada puncak acara World Education Forum. Pada pertemuan ini, seluruh gabungan stakeholders di dalam komunitas internasional yang mencakup perwakilan dari organisasi kawasan, organisasi internasional, Lembaga donor, organisasi non-pemerintah, grupgrup masyarakat sipil, dan 164 negara dunia memunculkan kerangka aksi Dakkar (Dakkar Framework of Action) untuk mewujudkan agenda EFA hingga tahun 2015 (Benavot et al. 2016). Hingga pada akhirnya, UNESCO ditunjuk sebagai pemimpin serta koordinator global dalam memimpin agenda EFA. Namun penunjukan UNESCO sebagai koordinator EFA memuat problematika terkait kapasitas material UNESCO yang pada dasarnya memiliki keterbatasan finansial dan kompleksitas tata kelola organisasi yang dianggap tidak cukup mampu memimpin agenda EFA.

Kapasitas material sangat penting di dalam sebuah agenda yang bertujuan membenamkan serangkaian prioritas agenda global ke dalam agenda pendidikan nasional. Karena kapasitas material sebagai kekuatan sosial, di dalam pandangan Cox, tidak berhenti hanya pada kekuatan material semata, namun mencakup produksi ideide, makna-makna intersubjektif, norma-norma, serta institusi-institusi yang menjadi lapangan bagi praktik sosial (Moolakkattu 2009). Pada permainan realitas politik yang mutakhir, kapasitas material berkaitan erat dengan kapasitas immaterial, keduanya sangat penting untuk saling menopang dalam rangka membangun kapasitas material. Oleh karena produksi material tanpa produksi ide tidak akan menemukan signifikansi simbolis di dalam kontestasi agenda global, begitu juga sebaliknya produksi ide tanpa adanya produksi material hanya akan menjadi tujuan mulia tanpa aksi nyata. Pada perspektif ini, keberadaan UNESCO sebagai pemimpin dan koordinator EFA memiliki kekurangan modalitas untuk dapat bergerak secara otonom dalam mengartikulasikan agenda prioritas EFA terhadap negara-negara berkembang. Dikarenakan anggaran tahunan UNESCO sendiri sangat tergantung terhadap kontribusi negara-negara maju.

Mengacu pada pemikiran tersebut, artikel ini secara kritis melihat keberadaan EFA 
sebagai gagasan yang tidak terlepas dari struktur kapitalisme global yang memunculkan ketimpangan antara negara maju dengan negara berkembang dan negara miskin. Pada kenyataannya, semua yang terjadi dan telah dicapai dari agenda EFA sejak pertemuan negara-negara dunia di Jomtien, Thailand berupa agenda yang telah disetujui, hingga lahirnya Dakar Framework of Action pada tahun 2000, dilandaskan pada kesepakatan antara negara-negara berkembang dan negara-negara maju. Kontur dari kesepakatannya memuat tanggung jawab dan mandat yang diemban oleh masingmasing pihak untuk mencapai agenda EFA demi pendidikan untuk semua bangsa. Gambaran ini muncul di dalam Education f or All Global Monitoring Report (EFAGMR) 2008 oleh UNESCO yang berbunyi sebagai berikut;

The Dakar Framework for Action is built on a compact between developing countries and rich countries. Like any compact, it involves two-way responsibilities and obligations. Developing countries pledged to strengthen national education plans, tackle inequality and enhance accountability to their citizens. Governments of developed countries pledged to provide the aid needed to ensure that no credible strategy in the poorest countries would fail for want of finance. Since Dakar, both groups of countries have reinforced these pledges on numerous occasions (UNESCO 2008, 204).

Maka dari itu, dapat dipahami bahwa, kewajiban dari negara maju adalah menyediakan dana bantuan, sedangkan negara berkembang menjalankan agenda EFA sebagai silih telah menerima berbagai bantuan dan asistensi yang disediakan oleh institusi-institusi yang mengkoordinasikan serta mempromosikan EFA, terutama dalam hal ini UNESCO. Pada titik ini, kita akan bertanya, berapa jumlah dana yang telah dikumpulkan secara kolektif negara-negara maju untuk menopang agenda ini? Menurut estimasi UNESCO, dunia membutuhkan dana bantuan 11 milliar Dollar AS setiap tahunnya untuk mencapai target-target utama EFA sesuai kerangka Dakar yakni universal primary education (UPE), early childhood programmes dan literacy (UNESCO-GMR 2008, 204). Jika diakumulasikan 15 tahun rentang implementasi EFA, maka dibutuhkan dana sekitar 165 milliar Dollar AS. Menurut data rekapitulasi UNESCO di tahun 2015, dana bantuan yang telah digulirkan oleh negara-negara maju secara bilateral tercatat 102 milliar Dollar AS, peringkat pertama negara besar yang paling dermawan dalam menggulirkan bantuan pendidikan adalah Amerika Serikat sebesar 26 milliar Dollar AS, kemudian Jepang sebesar 10 milliar Dollar AS, diikuti Inggris Raya di posisi ketiga sebesar 10 milliar Dollar AS (UNESCO-GMR 2015, 399). Sedangkan dana bantuan yang digulirkan secara multilateral dari berbagai institusi menurut laporan tersebut tercatat sejumlah 39 milliar Dollar AS di tahun 2013. Jika dijumlahkan kedua skema tersebut, telah terkumpul sekitar 141 milliar Dollar AS. Meskipun menurut UNESCO, aksi penggalangan dana tersebut masih belum mencapai estimasi yang telah dibuat dikarenakan pendidikan bukanlah sektor yang mendapatkan prioritas di dalam skema bantuan dunia (UNESCO-GMR, 2009). Namun jumlah tersebut sangat besar adanya, terutama jika tujuan utamanya adalah mengundang negara-negara berkembang untuk terhisap di dalam agenda EFA beserta seluruh definisinya terkait pendidikan. Pada dasarnya, UNESCO sebagai salah satu dari UN agency, memiliki ketergantungan yang sangat erat dengan negara yang berkontribusi terhadap anggaran tahunan untuk dapat beraktifitas secara Global. Kasus keluarnya Amerika Serikat dari UNESCO barubaru ini mengungkap realitas tersebut, implikasi dari pengakuan UNESCO terhadap Palestina sebagai negara berdaulat dengan diterima menjadi anggota, ketidaksenangan 
Amerika Serikat ditunjukan dengan memangkas dana kontribusi terhadap anggaran tahunan UNESCO sejumlah lebih dari 8o juta Dollar AS (22\% dari dana keseluruhan untuk UNESCO) yang kemudian ditindaklanjuti dengan keluar dari Organisasi ini (Foreign Policy 2017).

Sedangkan jika menelaah kondisi negara berkembang atau terbelakang yang melakukan rekonfigurasi kebijakan pada tingkat nasional untuk mengakomodasi EFA. Berdasarkan studi kasus di Sierra Leone, dengan melakukan observasi terhadap 27 sekolah di negara tersebut, terungkap bahwa sejak penerapan kebijakan sekolah gratis (a free primary education policy) yang berlandaskan pada agenda EFA, masalah utama yang muncul adalah meningkatnya akses terhadap pendidikan tidak serta-merta diikuti dengan meningkatnya kualitas dari pendidikan yang dilaksanakan di negara tersebut (Nishimuko 2007). Sejalan dengan penjelasan tersebut, Ishmael Munene (2016) di dalam buku "Achieving Education for All Dilemmas in SystemWide Reforms and Learning Outcomes in Africa" membuktikan melalui serangkaian data-data empiris di negara-negara kawasan Afrika bahwa meskipun pemerintahan negara-negara di Afrika merespons komitmen tujuan pendidikan dunia melalui komitmen masing-masing negara untuk melakukan difusi kebijakan pada tingkat nasional. Namun, ada jurang yang tidak bisa diabaikan yaitu,

"there remains a serious gap in knowledge about the design of these plans, the influence of local and international forces in their development, the challenges inherent in executing comprehensive and multifaceted reforms to achieve these goals, and the success of the reform measures as evident in student learning outcomes".

Meskipun paradigma EFA telah diterima secara luas di negara-negara Afrika, kemudian diimplementasikan melalui berbagai kebijakan di tingkat nasional, upaya tersebut tidak terbebas dari faktor-faktor kontradiktif yang termuat dalam upaya menerjemahkan adicita mulia pendidikan untuk semua. Terutama jika jangkauan pemahaman paling konkret untuk menunjukan komitmen tersebut adalah menerapkan pendidikan gratis di Afrika, sedangkan konsekuensi dari pendekatan tersebut, negara menjadi memiliki beban untuk menopang keberlangsungan pendidikan yang bebas biaya. Meskipun EFA didasarkan pada tujuan mulia yaitu untuk mempersempit jarak yang memisahkan negara maju dan terdidik dengan negara yang kurang maju dan terdidik, namun selubung adicita tersebut tidak bisa menolak kenyataan bahwa konsolidasi agenda pendidikan global tersebut tidak bisa terlepas dari moda produksi dominan yang menjadi landasan kapitalisme global. Sudah dapat dipastikan bahwa negara yang menadahkan tangan di bawah menjadi tidak memiliki kemampuan untuk menyuarakan aspirasinya dibandingkan negara-negara yang memiliki kapital sebagai instrumen untuk menopang agenda EFA sendiri.

\section{Hegemoni Education for All dan ide-ide universal}

Menurut pendekatan kritis Cox, tatanan hegemoni berlandaskan pada terbentuknya semacam blok historis yang diorganisasikan melalui artikulasi ide-ide dominan di dalam masyarakat internasional yang pada ujungnya membentuk basis-basis kolektif antar kelas-kelas sosial. Oleh karenanya, menurut Peter Burnham (1991) "A successful bloc is thereby politically organised through the exercise of 'intellectual 
and moral leadership' and forms the organic (long-term) as opposed to conjunctural (short-term) link between political and civil society". Pada dasarnya, EFA sebagai sebuah agenda pendidikan berasumsi bahwa kebijakan public dapat secara radikal mentransformasikan sistem Pendidikan dan hubungannya dengan masyarakat dalam waktu beberapa tahun, dengan adanya niat politik yang cukup dan sumberdaya yang memadai (UNESCO 2008). Oleh karena itu, untuk mendorong implementasi kebijakan publik pada tingkat nasional, perlu didorong melalui serangkaian komitmen yang dikampanyekan secara global. Rao dan Smyth (2005) mengatakan bahwa,

"Since the World Education Forum in Dakar, a wider participation in the goal to achieve EFA by 2015 has been strengthened, with an emphasis on the importance of civil society participation in planning, implementation, and monitoring. Aid allocation not only goes to governments, but also to NGOs and charity groups who work more closely with and for beneficiaries. This is because, currently, EFA is "everybody's business".

Dalam konteks ini EFA merupakan aksentuasi agenda pendidikan yang dipacu di lintasan sirkuit global dalam rangka melakukan ekstensifikasi dan intensifikasi tujuan yang memunculkan sebuah konsolidasi agenda pendidikan yang universal di seluruh dunia, sebuah agenda untuk mendorong negara-negara dunia melakukan difusi kebijakan di tingkat nasional.

Terkait ide yang memainkan peran sebagai kekuatan intersubjektif di dalam eksistensi EFA di dalam sistem internasional, tulisan ini berpijak pada keberadaan tujuan EFA yang menjadi suatu kesepakatan dan komitmen dunia dalam kaitan pendidikan. Pasca Deklarasi Dakkar, komitmen negara-negara dunia untuk untuk memperteguh implementasi EFA memiliki 6 tujuan utama yakni:Expanding and improving comprehensive early childhood care and education, especially for the most vulnerable and disadvantaged children. (2) Ensuring that by 2015 all children, particularly girls, children in difficult circumstances and those belonging to ethnic minorities, have access to, and complete, free and compulsory primary education of good quality. (3) Ensuring that the learning needs of all young people and adults are met through equitable access to appropriate learning and life-skills programmes. (4) Achieving a 50 per cent improvement in levels of adult literacy by 2015, especially for women, and equitable access to basic and continuing education for all adults. (5) Eliminating gender disparities in primary and secondary education by 2005, and achieving gender equality in education by 2015, with a focus on ensuring girls' full and equal access to and achievement in basic education of good quality. (6) Improving all aspects of the quality of education and ensuring excellence of all so that recognized and measurable learning outcomes are achieved by all, especially in literacy, numeracy and essential life skills (UNESCO.org).

Ide-ide universal tersebut memainkan peran sebagai kekuatan intersubjektif di dalam benak antar aktor, dengan makna-makna intersubjektif yang direproduksi aktor di dalam interaksinya berperan sebagai makna bersama yang melandasi hakekat alami hubungan antar aktor di dalam sistem internasional dikonsolidasikan menuju satu tujuan yakni 6 agenda prioritas di dalam membangun pendidikan pada aras nasional sesuai adicita EFA. 
Ide-ide tersebut tidak hanya berperan sebagai kekuatan intersubjektif namun juga memainkan peran memunculkan citra bersama (Collective Images) yang dipatuhi sebagai sebuah tatanan di dalam tata kelola pendidikan universal. Adapun keberadaannya memberikan pemahaman terhadap aktor terkait sifat alami dan legitimasi dari relasi kekuasaan yang unggul, makna keadilan dan kebaikan publik, dan seterusnya (Cox 1981, 136). Relevansi konsep tersebut dalam memahami EFA sebagai ide yang berusaha melakukan reproduksi makna terkait pendidikan di dalam benak negara-negara dunia terletak pada fungsi strategis pendidikan yang dipercaya menjadi jalan untuk membangun negara yang kuat dan kompetitif. Oleh karena itu, setiap negara di dunia ini pasti menginginkan sistem pendidikan yang terbaik, terutama untuk negara-negara berkembang atau kurang berkembang yang sangat mendambakan sistem pendidikan yang layak untuk rakyatnya. Namun, setiap dinamika yang dilalui negara dalam membangun eksistensinya di dalam sistem internasional melalui serangkaian aksi, reposisi dan aktualisasi wacana yang berperan secara holistik, negara yang seharusnya memiliki kedaulatan untuk menentukan sistem pendidikannya tidak sepenuhnya otonom dikarenakan di bawah tekanan globalisasi ekonomi yang menuntut negara untuk menjadi lebih kompetitif di dalam persaingan global. Bahkan menurut Carnoy (2016),In a globalized environment, the pressure for states to engage with education has increased. Globalization means increased competition among nations in a more closely intertwined international economy, a competition that is continuously enhanced by more rapid communication and computer technology and by a way of business thinking that is increasingly global rather than regional or national.

Dalam cara berpikir ini pendidikan didasarkan dalam sistem internasional yang saat ini sudah semakin terjejaring sebagai konsekuensi logis dalam dunia yang menganggap globalisasi sebagai konsep yang telah melanda seluruh aspek dalam kehidupan manusia.

Agenda Universal EFA yang secara integral ingin mendorong meningkatnya akses pendidikan di seluruh dunia, memang mendorong kuantitas peserta didik, namun justru masalisasi peserta didik menuntut kecakapan negara membangun sistem pendidikan yang dapat menghadirkan pendidikan yang berkualitas. Untuk negara berkembang, masalah pendidikan masih menjadi tugas rumah yang sangat kompleks, karena rasionalisasi kualitas dari sistem pendidikan harus ditopang oleh basis material dan immaterial yang kuat, prakondisi tersebut merupakan sebuah kemewahan untuk negara berkembang, apalagi negara miskin yang masih terbelakang. Oleh karena itu, seturut dengan agenda universal tersebut, seluruh stakeholders di dalam proses pendidikan dihadapkan pada kondisi problematis yakni; pada satu sisi, meningkatnya akses terhadap pendidikan mendorong masalisasi peserta didik, namun pada sisi lain, semakin mengekspos keterbatasan negara yang miskin infrastruktur untuk menunjang proses belajar-mengajar yang berkualitas.

Kasus-kasus yang menunjukan kegagalan implementasi EFA di negara-negara Afrika (sebagai catatan, Indonesia juga negara yang mengikuti agenda EFA) merupakan konsekuensi dari Kerangka Aksi Dakkar yang menuntut negara-negara dunia untuk mengalokasikan sumberdaya yang cukup untuk komponen pendidikan dasar. Hal ini akan membutuhkan peningkatan bagian dari pendapatan nasional dan anggaran yang dialokasikan pada pendidikan, termasuk pendidikan dasar (Benavot et al. 2016). 
Namun pada kenyataannya, lembaga-lembaga donor dunia banyak yang enggan untuk menjadikan agenda pendidikan sebagai prioritas utama bantuan dunia. Seperti yang diungkap oleh UNESCO, bahwa pendidikan terus diabaikan dalam sistem bantuan kemanusiaan yang sudah kekurangan sumber daya (UNESCO 2011). Adapun data yang diungkap untuk menjelaskan pernyataan tersebut menunjukan bahwa pendidikan mendapatkan proporsi bantuan humaniter yang sangat kecil yakni 40\% dari kebutuhan riilnya, sangat jauh jika dibandingkan dengan bantuan di sektor pangan yang mencapai $86 \%$, juga terpaut cukup jauh jika dikomparasikan dengan bantuan di sektor kesehatan yang mencapai $57 \%$.

Pada titik ini, negara-negara berkembang harus kembali kepada kapasitas masingmasing untuk dapat mencapai agenda EFA, pertanyaan yang muncul pada titik ini adalah mengapa negara harus hirau terhadap agenda universal yang belum tentu kompatibel dengan kemampuan nasionalnya? Menurut Joel Spring (2014), "The growth of worldwide educational institutions, networks, and discourses has led to similar national educational agendas, particularly the concept of education as an economic investment. Consequently, educational discourses around the world often refer to economic growth, teaching work-related skills, and lifelong learning for work".

Pemahaman ini ditangkap oleh Joel Spring sebagai sebuah "Global Education Superstructure”. Di dalam kerangka Global Education Superstructure, hegemoni EFA ditegakkan. Konteks yang membalut realitas tersebut cenderung memuat dimensi kontestasi politik dibandingkan ketersediaan finansial. Dikarenakan ide universal EFA yang menyasar meningkatnya akses pendidikan secara massif memiliki konsekuensi bagi negara yang tidak menerapkan agenda tersebut dapat ditekan sebagai negara yang tidak mendukung adicita humanis pendidikan, sedangkan pada tingkat nasional, elit politik negara-negara berkembang harus mampu menghadapi tekanan politik domestik yang menuntut kebijakan pro-poor terutama pada sektor pendidikan. Kritik tersebut menemukan argumentasi pendukungnya dalam ungkapan berikut.

That many states choose to adopt globally induced education policies that lower costs without improving quality (particularly in higher levels of education) is at least partly the result of caving in to "pro-poor" politics in the face of new competitive pressures and new, globalized thinking (Carnoy 2016).

Dalam kaitan ini, kecemasan yang mengetengah berpijak pada kenyataan bahwa negara-bangsa sekarang ini tidak sepenuhnya berdaulat dalam konteks formulasi kebijakan pendidikan dikarenakan adanya mandat serta himbauan organisasi internasional yakni UNESCO yang mampu memberikan pengaruh dalam mendorong perkembangan sistem pendidikan di negara-negara dunia. Pada titik ini, penekanan diskursus pendidikan secara universal menjadikan konsep hegemoni menemukan arti pentingnya. Alasannya sederhana, di dalam kecemasan terhadap potensi ketidakberdayaan negara terkait ikatan konsensual non-koersif dengan agendaagenda pendidikan global, masa depan global civil society dipertaruhkan. Ketiadaan pemahaman terkait eksistensi top-down civil society yang sengaja dan terstruktur dibentuk kekuatan hegemonik dalam melanggengkan status-quo, akan menjegal keberadaan bottom-up civil society yang diharapkan dapat menghadirkan gelombang balik sebagai reaksi dialektis untuk melakukan counter-hegemony terhadap kekuatan hegemonik (Cox 1999). Adapun nalar masyarakat global harus mampu 
menangkap kontestasi tersebut. Lebih jauh lagi, bukankah Antonio Gramsci sendiri memformulasikan konsep hegemoninya berlandaskan pada pentingnya pendidikan sebagai sebuah aspek yang menentukan dalam melakukan transformasi sosial hingga terbentuknya sebuah dominasi kelas sosial sehingga dapat dipahami (Gramsci 1971, 350 ).

\section{Simpulan}

Pada akhirnya, penulis telah menuntaskan tujuan awal narasi intelektual artikel ini yang berniat fokus kepada dinamika agenda Education for All (EFA) sebagai agenda pendidikan dunia. Setelah melakukan analisis kritis terhadap agenda tersebut, pertanyaan utama yang diajukan yakni bagaimana EFA sebagai agenda pendidikan global membenamkan hegemoni etisnya terhadap trajektori kebijakan pendidikan negara-negara berkembang? Pertanyaan tersebut telah dijawab dengan menggunakan pendekatan Cox dalam memahami World Orders sebagai sebuah arena tempat kekuatan sosial diproduksi; klaim artikel ini telah dipertahankan dengan menunjukan hegemoni EFA sebagai sebuah agenda pendidikan dunia terhadap negara-negara berkembang berpijak pada proses institutionalisasi agenda pendidikan secara global menggunakan keberadaan organisasi internasional, kapasitas material agenda yang ditopang oleh negara-negara maju serta kesenjangan kemapanan ekonomi negara berkembang yang menjadikan agenda EFA menjadi suatu beban untuk dapat dicapai. Kemudian pada akhir analisis, ide universal untuk membangun konsensus global terkait trajektori pendidikan dunia ditelaah dalam konteks kontestasi politik yang membalut keberadaannya. Artikulasi ketiga aspek tersebut menopang hegemoni EFA terhadap negara berkembang dan terbelakang, hingga pada akhirnya artikel ini memperteguh keyakinan intelektualnya yakni every relationship of hegemony is an educational one.

\section{Daftar Pustaka}

\section{Buku dan Bab dalam Buku}

Benavot, Aaron, et al, 2016. Education for All 200O-2015. The Handbook of Global Education Policy, 241-258.

Carnoy, Martin, 2016. Educational policies in the face of globalization: Whither the nation State. In Teoksessa K. Mundy, A. Green, B. Lingard \& A. Verger (toim.), The handbook of global education policy. Chichester, uk, 27-42.

Cox, Robert, 1986. "Social forces, states and world orders." Neorealism and its Critics 207.

Finnemore, Martha, and Judith Goldstein, 2013. eds. Back to basics: State power in a contemporary world. Oxford University Press.

Friedman, Thomas, 1999. The Lexus and the Olive Tree: Understanding Globalization. New York: Farrar, Straus, and Giroux.

Gill, Stephen, 2002. Power and Resistance in the New World Order, Palgrave, 
Macmillan: 58.

Gramsci, Antonio. Selections from the Prison Notebooks of Antonio Gramsci: Ed. and Transl. by Quintin Hoare and Geoffrey Nowell Smith. Eds. Geoffrey NowellSmith, and Quintin Hoare. International Publishers, 1971.

Hadiwinata, B. S., 2002. Politik Bisnis Internasional. Kanisius.

Harvey, David, 1989. The Condition of Post-Modernity: An Enquiry into the Conditions of Cultural Change. Oxford: Wiley-Blackwell.

Munene, Ishmael I., 2017. Achieving Education for All: Dilemmas in System-Wide Reforms and Learning Outcomes in Africa. ed. by Ishmael I. Munene, and: Education in West Africa ed. by Emefa J. Takyi-Amoako. Africa Today, 63(3), 112-113.

Power, Colin, 2014. The Power of education: Education for all, development, globalisation and UNESCO (Vol. 27). Springer.

Rao, Nitya. and Ines Smyth, 2005. Partnerships for Girls' Education. Oxford: Oxfam.

Spring, Joel, 2014. Globalization of education: An introduction. Routledge.

Spring, Joel, 2015. Economization of education: Human capital, global corporations, skills-based schooling. Routledge.

Sugiono, Muhadi, 1999. Kritik Antonio Gramsci terhadap pembangunan dunia ketiga. Pustaka Pelajar.

UNESCO. 2015. Education for All 200O-2015: Achievements and Challenges. Paris: UNESCO

\section{Jurnal dan Jurnal Daring}

Augelli, E., and Murphy, C. N, 1993. "Gramsci and international relations: a general perspective with examples from recent US policy toward the Third World." Cambridge Studies in International Relations, 26 (1): 127-127.

Bates, Thomas R, 1975. "Gramsci and the Theory of Hegemony." Journal of the History of Ideas, 36 (2): 351-366.

Burnham, Peter, 1991. "Neo-Gramscian hegemony and the international order." Capital \& Class, 15 (3): 73-92.

Cox, Robert W, 1993. "Gramsci, hegemony and international relations: an essay in method.” Cambridge Studies in International Relations, 26: 49-49.

Cox, Robert W, 1999. "Civil society at the turn of the millenium: prospects for an alternative world order." Review of international studies, 25 (1) : 3-28.

Dale, Roger, 2000. "Globalization and education: Demonstrating a "common world 
educational culture" or locating a "globally structured educational agenda"?." Educational Theory, 50 (4): 427-448.

Evans, G., 2004. Local meanings, global schooling: anthropology and world culture theory. Journal of the Royal Anthropological Institute, 10 (3): 716-718.

Femia, Joseph, 1975. "Hegemony and Consciousness In The Thought Of Antonio Gramsci*." Political studies, 23 (1): 29-48.

Finnemore, Martha., \& Katryn Sikkink, 1998. "International norm dynamics and political change.” International organization, 52 (4): 887-917.

Fuchs, E., 2007. "Networks and the History of Education.” Paedagogica Historica, 43 (2): 185-197.

Moolakkattu, J. S., 2009. "Robert W. Cox and critical theory of international relations." International Studies, 46 (4): 439-456.

Nishimuko, M., 2007. "Problems behind education for all (EFA): The case of Sierra Leone." Educate , 7 (2): 19-29.

Ruggie, J.G., 1982. "International regimes, transactions, and change: embedded liberalism in the postwar economic order." International organization, 36 (2): $379-415$.

Ruggie, J.G., 1993. "Territoriality and beyond: problematizing modernity in international relations." International organization, 47 (1): 139-174.

Ruggie, J. G., 1998. "What makes the world hang together? Neo-utilitarianism and the social constructivist challenge.” International organization, 52 (4): 855-885.

Singh, Madhu, 2002. "The global and international discourse of lifelong learning from the perspective of UNESCO.” Lifelong Learning: One Focus, Different Systems.

Frankfurt: 11-22.

\section{Artikel Daring}

Foreign Policy 2018. "U.S. to Pull Out of UNESCO, Again" [Daring]. Tersedia di http://foreignpolicy.com/remote-login.php?login=10e43f3bo1eb1e555b643769334 co757\&id $=71129472 \& u=41384 f 795940 c o b 8 f 33 c 1 f c c c a 002 b 1 d \& h=$ [Diakses 1 Juni 2018].

UNESCO, tt. "International Implementation Scheme (IIS)". [Daring]. Tersedia di http://portal.unesco.org/education/en/ev.phpURL_ID $=23280 \& U R L$ DO=DO_TOPIC\&URL_SECTION =201.html. [Diakses 17 Maret 2016] UNESCO 2016. "Global Education Monitoring Report" [Daring]. Tersedia di https://en.unesco.org/gem-report/node/58 [Diakses 1 Juni 2010]. 
UNESCO, tt. "The Six EFA Goals" [Daring]. Tersedia di http://portal.unesco.org/en/ ev.php-URL_ID=22012\&URL_DO=DO_TOPIC\&URL_SECTION=201.html [Diakses 1 Juni 2018].

Paudni.kemdikbud.go.id 2014. “Ini Pencapaian PUS 2000-2015” [Daring]. Tersedia di http://paudni.kemdikbud.go.id/berita/5109.html_[Diakses 1 Juni 2018].

Kompas.com 2014. "Anies Baswedan Sebut Pendidikan Indonesia Gawat Darurat" [Daring]. Tersedia di https://edukasi.kompas.com/read/2014/12/01/13455441/ anies.baswedan.sebut.pendidikan.indonesia.gawat.darurat [diakses 1 Juni 2018]

Litbang.kemdikbud.go.id. "Survei Internasional PISA" [Daring]. Tersedia di http:// litbang.kemdikbud.go.id/index.php/survei-internasional-pisa [diakses 8 Mei 2016]

\section{Lain-lain}

UNESCO. 2008. Education for All Global Monitoring Report 2009, Overcoming Inequality: Why Governance Matters. Paris: UNESCO.

UNESCO. 2010. Education for All Global Monitoring Report 2010: Reaching the Marginalized Paris: UNESCO.

UNESCO. 2011. Education for All Global Monitoring Report 2011: The Hidden Crisis: Armed Conflict and Education. Paris: UNESCO. 
A Coxian Approach: Mengungkap Hegemoni Agenda "Education For All” Terhadap Negara Berkembang 